\title{
Yaratıcı Dramanın Öğretmen Adaylarının Bilişüstü Farkındalıkları Üzerindeki Etkisi
}

\author{
Ebru Selçioğlu Demirsöz ${ }^{1}$
}

$\ddot{O}_{z e t}$

Bu araştırma ile Dokuz Eylül Üniversitesi Buca Eğitim Fakültesi İlköğretim Bölümü Sinıf Öğretmenliği Anabilim Dalı Programı'nda yetişmekte olan 3. sınıf öğretmen adaylarının bilişüstü farkındalıkları üzerinde yaratıcı drama eğitimi ve geleneksel öğretim yönteminin etkilerini ortaya koymak amaçlanmıştır. Araştırma modeli 2x2 Solomon dört gruplu deneysel desendir. Böylelikle çalışmada aynı zamanda ön testin sonuçlar üzerinde herhangi bir etkisinin olup olmadı̆̆ı da araştırılmıştır. Insan Hakları dersinde sürdürülen çalışmada deney gruplarında yöntem olarak yaratıcı drama, kontrol gruplarında ise geleneksel ögretme yöntemi uygulanmıştır. Çalışma grubunu her grupta 30 ögretmen adayı olan toplam 120 ögretmen adayı oluşturmaktadır. Araştırmanın verileri, Schraw ve Dennison (1994) tarafindan geliştirilen ve Selçioğlu Demirsöz' ün (2010) dil eşdeğerliğini yapmış olduğu BFÖ (Bilişüstü Farkındalık Ölçeği) ile toplanmıştır. Bilişüstü Farkındalık Ölçeğinin ön test toplam Cronbach's Alpha güvenirlik katsayısı $\alpha=0,94$, son test toplam Cronbach's Alpha güvenirlik katsayısı $\alpha=$ 0,93 olarak oldukça yüksek düzeyde güvenilir bulunmuştur. Araştırmadan elde edilen bulgulara göre; Bilişüstü farkındalık bakımından; deney ve kontrol gruplarının son testleri arasında ölçeğin bütününde ve alt ölçeklerinde anlamlı farklılı yoktur. Deney grubunun ön test - son test sonuçları arasında ölçeğin bütününde ve alt ölçeklerinde son test lehine anlaml farklılık elde edilmişken, kontrol grubunda anlaml farklılık elde edilememiştir. Ayrıca ön testin yapılmasının bilişüstü farkındalık bakımından deney ve kontrol gruplarında ögrenme ve duyarlılaşmaya etkisi saptanmamıştır.

Anahtar Sözcükler: Bilişüstü Farkındalık, Yaratıcı Drama, Öğretmen Eğitimi

\section{Effects of Creative Drama on Metacognitive Awareness of the Teacher Trainees}

\begin{abstract}
The purpose of this research is to understand the effects of traditional teaching technique and creative drama education on metacognitive awareness of the 3rd year teacher trainees studying at the Department of Primary School Teacher Training, Buca Faculty of Education in Dokuz Eylül University. The model of the study was $2 x 2$ Solomon four grouped empirical design. Also in this way it is searched that if there is an effect of pre testing on results. The study was carried out through the Human Rights course of the program and was applied by the researcher. The method for the experimental groups was creative drama where the control groups received traditional teaching methods. Experimental Group 1 and Control Group 1 were given "Metacognitive Awareness Scale" in the beginning of the study; where the Experimental Group 1, Experimental Group 2, Control Group 1, Control Group 2 were given the same scales as post test. The study group consisted of 120 teacher trainees divided as 30 students for each group. Datas of the research gained through MAS (Metacognitive Awareness Scale) which is developed by Schraw and Dennison (1994) and Selcioglu Demirsoz (2010) has done the language equivalence. Pretest total Cronbach's Alpha reliability coefficient $\alpha=0,94$, posttest total Cronbach's Alpha reliability coefficient $\alpha=0,93$ according to this result Metacognitive Awareness Scale has found highly reliable. The results of the study were as follows: In terms of metacognitive awareness, there was no significant difference in complete and sub-scales of the posts tests applied to experimental and control groups. There was a significant difference to the advantage of post test between pre test and post test results of the experimental groups (complete scale and
\end{abstract}

1 Yrd. Doç. Dr. Trakya Üniversitesi Eğitim Fakültesi Sınıf Öğretmenliği Anabilim Dalı 
sub-scale); however, no such difference was obtained for the control group. In addition, there were no effects of the pre test performance on the experimental and control groups towards the learning and sensitiveness in terms of metacognitive awareness.

Keywords: Metacognitive Awareness, Creative Drama, Teacher Trainees

Giriş

Birey belli bir zaman ve yerde öğrendiği bilgiyi, istediği yer ve zamanda uygulama yetisine sahiptir. Bu durum bireyin öğrenilen bilgileri bir yerde depolama kapasitesine sahip olduğunu göstermektedir. Bireyin bilgiyi toplama, örgütleme, depolama ve hatırlama aşamalarıyla ilgilenen bilgiyi işleme kuramına göre öğrenme, bireyin sahip olduğu bazı yapılar ve bu yapılarla ilintili süreçler sonunda gerçekleşir.

Bireyin öğrenme sırasında gerçekleştirdiği bu bilişsel süreçlerin ve stratejilerin farkında olması ve öğrenmesini yönlendirmesi bilişüstü (metacognition) kavramı ile açıklanmaktadır. Bilişüstü ile ilk çalışmaları yapan Flavell $(1976,1979)$ ' in tanımıyla bilişüstü, anlamayı izleme ve özdenetimi de içerecek biçimde kişinin kendi bilişsel süreçlerinin farkında olması ve bunları kontrol edebilmesidir. Kendi zihinsel faaliyetlerini izleyebilme, gözlemleyebilme ve öğrenmenin özdenetimi gibi yetenekler bilişüstü becerileri oluşturmaktadır. Schraw ve Dennison (1994), bilişüstünü kişinin düşünme, anlama ve kendi öğrenmesini kontrol etme yeteneği olarak; bireyin kendi performansını direkt olarak yükseltecek bir yolda planlama, sıralama, izleme ve daha iyi uygulama yetisini ise bilişüstü farkındalık olarak tanımlar (Schraw ve Dennison ,1994).

Bilişüstü farkındalık kavramının temelinde bireyin bilinçli davranma, kendini kontrol etme, kendini düzenleme ve değerlendirme, planlama, nasıl öğrendiğini izleme ve öğrenmeyi öğrenme kavramları vardır. Yani birey kendisinin ve öğrenme yollarının farkındadır. Buna dayanarak bilişüstü farkındalık, bireyin hayatı boyunca gereksinim duyacağı bilişüstü düşünme becerilerini kazanma ve kullanma işi olarak tanımlanabilir. Flavell (1987: 21-30) bilişüstü bilgilerin deneyimler, hedefler ve eylemler arasındaki etkileşimler ve bunların hareketi yoluyla meydana geldiğini savunmaktadır.

Schraw ve Dennison (1994: 3), iyi düşünme, anlama ve kişinin öğrenimini kontrol etme olarak adlandır1lan bilişüstünün, Flavell tarafından sınıflandırılan "Biliş Bilgisi" ve "Bilişin Düzenlenmesi" iki ana bileşeninin zamanla diğer araştırmacılar (Brown, 1987; Flavell, 1987; Jacobs ve Paris, 1987) tarafından genişletilerek alt bileşenlerinin belirlendiğini ifade etmektedir. Böylelikle biliş hakkında bilgi olan "Biliş Bilgisi"; bilişüstünün yansıtmalı bakış açısını kolaylaştıran üç alt-süreci içerir. Bunlar; tanımsal (ifade) bilgi (ör; kendisi ve stratejileri hakkındaki bilgi), yöntemsel (süreç) bilgi (ör; stratejilerin nasıl kullanılacağına ait bilgi) ve durumsal (şartsal) bilgidir (ör; stratejileri ne zaman ve neden kullanacağımız bilgisi). "Biliş Düzenlenmesi" ise bireyin öğrenme bakış açısını kontrol etmeyi kolaylaştıracak beş alt-süreci içerir. Bunlar; planlama, bilgi yönetim stratejileri, gözlemleme (kendini izleme), hata ayıklama (onarma) stratejileri ve değerlendirmeyi içeren düzenleme becerileridir.

Blakey ve Spence (1999: 11-13) bilişüstü stratejileri geliştirmek için aşamalı olarak şunların yapılmasını önermişlerdir:

1. Ne bildiği ve ne bilmediğinin tanımlanması, ön bilgi araştırması,

2. Düşündüklerini ifade etme,

3. Düşünce günlüğü tutma,

4. Plan yapma ve kendi kendini düzenleme,

5. Düşünme sürecini sorgulama,

6. Kendini değerlendirme.

Bazı öğrenciler bilişüstü becerilerini kademe kademe yeteri oranda geliştirirken, bazıları da geliştirememektedir. Öğrencilere bilişüstü becerilerin öğretimi, onların başarılarında önemli bir artışa neden olabilir. Öğrenciler 
kendi düşünce süreçleri üzerinde düşünebilmeyi öğrenirler ve zor işlerde kendi başlarına düşündükleri belirli öğrenme stratejilerini uygularlar. Düşünme becerileri ve çalışma becerileri bilişüstü becerilerinin örnekleridir. Öğrencilere kendi kavrayışlarını değerlendirmek, problemleri çözmek, çalışmak için ne kadar zamana ihtiyacı olduğunu belirlemek veya çalışmak için etkili bir plan geliştirmek amacı ile bilişüstü beceriler öğretilebilir. Bilişüstü beceriler, anlamadığınız zaman nasıl bilmeniz gerektiğini ve kendinizi nasıl düzeltmemiz gerektiğinin farkındalığıdır (Slavin, 2003: 203). Johnson (2002: 595-602)' un “Drama and Metacognition” adlı çalışmasında aktardığı üzere drama deneyimine katılmak ve drama deneyiminin yansımaları bireyin düşünme yetileri ve bilişüstü farkındalığı üzerinde etkilidir. Drama, bireyin bilgi ve anlayışı kavrayabilecekleri ve kavramları keşfedebilecekleri bir öğrenme aracıdır. Katılımcısına sınırsız sayıda ortam yaratma kapasitesi sunar. Örneğin bir devin şatosunun içinden Frank'ın Amsterdam'daki gizli çatı arasına ve bir köyün postanesinden Mars'taki bir uzay istasyonuna dek çeşitli mekân ve durumlar dramada elimizin altındadır. Katılımcılar durumları birbirileri ile iletişim halinde ve öğretmenin de katılımı ile ilk olarak bu ortamları mevcut bilgileri ile ve bazen de bildiklerini bilmedikleri bazı bilgilerini kullanarak yaratırlar. Bu hayali dünyaları bir hikaye ya da durumun özelliklerinden yola çıkarak oluşturabilirler. Bu türden bir çalışma, düşünme ve dil yetileri üzerinde oldukça önem kazanmaktadır. Mercer (1998) zihinsel gelişimi, dilin kullanılmasının temel rollerden birini oynadığı "diyaloglar halinde sürdürülen, etkileşimli, kültürel hassasiyeti olan” bir süreç olarak tanımlamaktadır.

Drama yoğun bir şekilde sözel, görsel ve kinestetik öğrenme olanakları sağlamaktadır. Johnson (2002) dramanın katılımcılardan talep ettiği düşünme türlerini "yüksek nitelikli düşünme” olarak adlandırmış ve bu özellikler ile drama arasındaki ilişkiyi şöyle sunmuştur:

Tablo 1. Bilişüstü Farkındalık ve Drama İlişkisi

\section{Bilişüstü Farkındalık (Yüksek Nitelikli Düşünme)}

\section{Drama}

Karmaşık olma eğilimi gösterir - toplam kompozisyon tek bir bakış açısı ile görülemez

Birbirleri ile çelişen kriterler içerebilir

Anlam yükleme gerektirir - düzensizlik içindeki yapının düzenlenmesidir
Drama, rol oynama eylemi ile aynı durumun farklı karakterlerin gözünden farklı algılanışlarını gösterir. Doğrusal bir süreç değildir.

Drama, problem çözme ve ikilemlerin çözülmesini hem dramanın konusu hem de dramanın oluşturulması sürecinde gerektirir.

Drama tamamen anlamların bulunması, oluşturulması ve iletilmesidir. İlk olarak öğretmen tarafından yapılandırılır ama çocuklar deneyim kazanıp drama yetilerini geliştirdikçe kendi dramalarını yapılandırma sorumluluğunu daha fazla alırlar ve performansları ile buldukları anlamları diğerlerine aktarırlar.

Bu bağlamda, yaratıcı drama deneyimine katılmak ve drama deneyiminin yansımaları bireyin düşünme yetileri ve bilişüstü farkındalığı üzerinde etkilidir. Çünkü yaratıcı drama, bilginin kavranmasında ve kavramların keşfedilmesinde önemli bir öğrenme aracıdır. Yani yaratıcı drama, katılımcısının düşünme gelişimini destekleyen önemli bir yöntemdir.

\section{Amaç}

Öğretmen eğitiminde akademik tutum ve davranışlarının oluşmasında, öğretmen adayının etkili öğretim stra- 
tejisi geliştirebilme ve uygulayabilme yeterliliği olan bilişüstü farkındalığı önemli bir yer tutar. Bu nedenle, araştırmada öğretmen adaylarının bilişüstü farkındalıklarını öğrenci merkezli olan ve karar verme sürecinde öğrenciye öğrenme hakkı tanıyan, öğrenmeleri bilişsel, devinişsel ve duyuşsal boyutta destekleyen yaratıcı drama yöntemi yoluyla geliştirecek bir program hazırlanılarak, bu programın Dokuz Eylül Üniversitesi Buca Eğitim Fakültesi İlköğretim Bölümü Sınıf Öğretmenliği Anabilim Dalı Programında yetişmekte olan 3. sınıf öğretmen adayları üzerinde denenmesi ve bilişüstü farkındalıkları üzerindeki etkilerinin araştırılması amaçlanmıştır. Bu araştırma ile sınıf öğretmeni yetiştirme programı ile ilgili olarak, bundan sonra yapılacak olan çalışmalarda işe yarayacak sonuçlar, öneriler, modeller geliştirilmesi, yeni düşünce ve araştırma konuları yaratılması hedeflenmektedir.

\section{1. Çalışmanın Denencesi}

Yaratıcı drama eğitimiyle yetişen sınıf öğretmeni adayları ile geleneksel öğretim yöntemiyle yetişen sınıf öğretmeni adaylarının bilişüstü farkındalık düzeyleri arasında anlamlı farklılıklar vardır.

\section{Araştırmanın Yöntemi}

\section{Araştırma Deseni ve İşlem}

Araştırma deseni 2x2 Solomon dört grup modeli deneysel desendir. Solomon dört grup modeli, iç ve diş geçerliği birlikte koruyan en kuvvetli deneme modelidir. Solomon deneysel desende iki deney, iki kontrol grubu bulunmaktadır. Bunlardan ilk deney ve kontrol grubu araştırmada kullanılan veri toplama aracını ön test ve son test olarak alırken, ikinci deney ve kontrol grubu ise veri toplama aracını sadece son test olarak almaktadır (Graziano ve Raulin, 2004: 232; Fraenkel ve Wallen, 2003: 274; Gall, Gall, Borg, 2003: 411-413; Rasnow ve Rosenthal, 2002: 170; Karasar, 2000: 98; Dawson, 1997: 17-18; Sawilowsky, Kelley, Blair, Markman, 1994: 1-2; www.socialresearchmethods.net/kb/exphybrd.php). Solomon dört grup modeli, ilk deney ve kontrol grubunda uygulanan ön test ve son testler aracılığıyla bağımsız değişkenin sonuç üzerindeki etkisini göstermenin yanında ikinci deney ve kontrol grubunda ön testin uygulanmaması nedeniyle ön testin sonuçlar üzerinde herhangi bir etkisinin olup olmadığı konusunda araştırmacıya fikir verir (Rasnow ve Rosenthal, 2002: 170). Solomon deneysel deseni ile;

1. kontrol grubuna ilişkin olarak deney grubunun farklaşması,

2. ön test etkileşimi (öğrenme, duyarlılaşma gibi)

3. ön test- son test arasındaki farklılık araştırılmaktadır (Gall, Gall, Borg, 2003: 411).

Yapılmış olan bu araştırmada, öğretmen adaylarının fakülte programını takip etme ve kayıtlı oldukları şubelerde derse girme zorunluluğu nedeni ile, deneklerin gruplara yansız olarak rastgele atanması mümkün olamayacağı için çalışma yarı deneysel desen olarak tasarlanmıştır.

Tablo 2. Araştırmada Kullanılan Deney Deseni

\begin{tabular}{|l|c|c|c|c|}
\hline Grup No & Grup Ad1 & Ön-test & Deneysel İşlem & Son-test \\
\hline G1-R & Deney 1 & BFÖ & Yaratıcı Drama & BFÖ \\
\hline G2-R & Kontrol 1 & BFÖ & $\begin{array}{c}\text { Geleneksel Öğrenme } \\
\text { (denel işlem yok) }\end{array}$ & BFÖ \\
\hline G3-R & Deney 2 & - & Yaratıcı Drama & BFÖ \\
\hline
\end{tabular}




\begin{tabular}{|l|l|l|c|c|}
\hline G4-R & Kontrol 2 & - & $\begin{array}{c}\text { Geleneksel Öğrenme } \\
\text { (denel işlem yok) }\end{array}$ & BFÖ \\
\hline
\end{tabular}

Tablo 2' de görüldüğü gibi araştırmanın deney desenini iki deney, iki kontrol grubu oluşturmaktadır. Deney gruplarında yöntem olarak yaratıcı drama, kontrol gruplarında ise geleneksel öğrenme yöntemi uygulanmış ve öğretmen adayları bilişüstü farkındalıkları bakımından karşılaştırılmıştır. Deney 1 ve Kontrol 1 gruplarına araştırmanın başında ön test olarak verilmiş olan "Bilişüstü Farkındalık Ölçeğii” (BFÖ), araştırmanın sonunda Deney 1, Deney 2, Kontrol 1, Kontrol 2 gruplarına son test olarak uygulanmıştır. Araştırmada deneysel işlemleri gerçekleştirmek amacıyla araştırmacı tarafından deney ve kontrol gruplarında öğrenme-öğretme durumları için ders planları ve etkinlikler hazırlanmıştır. Deney grupları için hazırlanan günlük planlar ve etkinlikler yaratıcı drama yönteminin hazırlık-1sınma, canlandırma ve değerlendirme süreçlerine yönelik hazırlanmış, kontrol grupları için hazırlanan günlük planlar ise sürecin soru cevap ve tartışma yöntemleri ile işlenmesine olanak verecek şekilde düzenlenmiştir. Araştırma için on hafta deneysel uygulama olmak üzere, ön-test son-test uygulamaları ile beraber toplam 12 hafta çalışılmıştır. Deneysel çalışma sırasında kontrol gruplarında iki saatlik ders saati rahatlıkla yeterken, deney gruplarında etkinliklerin tamamlanması için iki ders saatinin dışına çıkılarak, teneffüs saatlerine de kaymalar olmuştur. Ancak bu duruma rağmen öğrencilerin etkinliği tamamlamada istekli oldukları gözlenmiştir.

\section{2. Çalışma Grubu}

Araştırmanın çalışma grubunu Dokuz Eylül Üniversitesi Buca Eğitim Fakültesi SınıfÖğretmenliği Anabilim Dalı'nda öğrenim görmekte olan her birinde 30 öğretmen adayının olduğu 4 şube oluşturmaktadır. Araştırmanın çalışma grubunun denekleri amaçlı örnekleme yöntemiyle belirlenmiştir. Bu yaklaşımın avantajı deneklerin seçiminde araştırmacının önceki bilgi ve becerilerini kullanmasıdır. Burada ortalama olarak istenen özellikleri taşıyanların seçilmesi bir yoldur (Balcı, 2001:102). Bununla beraber çalışma grubu, araştırmacının olanakları göz önünde bulundurularak, kolay ulaşılabilir durum örnekleme yöntemine (Yıldırım, Şimşek, 2000) de örnektir.

\section{Veri Toplama Aracı}

Bu araştırmada öğretmen adaylarının bilişüstü farkındalıklarını ölçmek için eğitim psikoloğu olan Gregory Schraw ve Rayne Sperling Dennison (1994) tarafından geliştirilen ve orijinali İngilizce olan "Metacognitive Awareness Inventory” Bilişüstü Farkındalık Ölçeği kullanılmıştır. Bilişüstü Farkındalık Ölçeği' nin dil eşdeğerliği çalışması araştırmacı tarafından yapılmış (Selçioğlu Demirsöz, 2010) ve Türkçe form mevcut örneklem için geliştirilmiştir. Bilişüstü Farkındalık ölçeği "Biliş Bilgisi”" ve "Biliş Düzenlemesi” adı verilen iki temel faktörden oluşmaktadır. Ölçeğin toplam Cronbach's Alpha iç tutarlılık katsayısı 0,93, Biliş Bilgisi alt boyutunun Cronbach's Alpha iç tutarlılık katsayısı 0,82 ve Biliş Düzenlemesi alt boyutunun Cronbach's Alpha iç tutarlılık katsayısı 0,91 olarak oldukça yüksek ve güvenilir bulunmuştur. Ölçek bu çalışmanın deneklerine uygulandığında Bilişüstü Farkındalık Ölçeği ön test toplam Cronbach's Alpha güvenirlik katsayısı $\alpha=0,94$, son test toplam Cronbach's Alpha güvenirlik katsayısı $\alpha=0,93$ olarak oldukça yüksek düzeyde güvenilir bulunmuştur. Bilişüstü Farkındalık Ölçeği alt boyutlarına baktığımızda ise, Biliş Bilgisi ölçeği ön test Cronbach's Alpha güvenirlik katsayısı $\alpha=0,83$, son test Cronbach's Alpha güvenirlik katsayısı $\alpha=0,85$ olarak oldukça yüksek; Biliş Düzenlemesi ölçeği ön test Cronbach's Alpha güvenirlik katsayısı $\alpha=0,93$, son test Cronbach's Alpha güvenirlik katsayısı $\alpha=0,90$ olarak yine oldukça yüksek seviyede bulunmuştur.

\section{Verilerin Çözümlenmesi}

Bu araştırmada toplanan verilerin çözümlenmesi için aşağıdaki istatistiksel yöntemler ve teknikler kullanılmıştır. 
1. Çalışma gruplardaki öğrencilerin ölçme aracından aldıkları puanların dağılımında aritmetik ortalama ve standart sapma,

2. Ölçeğin güvenirliklerini hesaplamada, Cronbach's Alpha katsayısı,

3. Araştırmadan elde edilen verilerin normal dağılım gösterip göstermediğini test etmek amacıyla Shapiro-Wilks testi,

4. Parametrik gruplarda ortalamalar arası farkın test edilmesinde bağımsız t-testi

5. Parametrik gruplarda ön test-son test etkileşimi için 2X2 Tekrarlı Ölçümler Anova ve İlişkili Örneklemler İçin T-testi, Kovaryans (ANCOVA) Analizi,

6. Parametrik olmayan gruplarda ortalamalar arası farkın test edilmesinde Mann Whitney U testi,

7. Parametrik olmayan gruplarda ön test-son test ortalamalar arası farkın test edilmesinde Wilcoxon İşaretli Sıralar testi kullanılmıştır.

Araştırmanın verileri SPSS 15 programında analiz edilmiştir. Araştırmada elde edilen verilerin dağılımını incelemek ve normal dağılım gösterip göstermediğini test etmek için deney ve kontrol gruplarının Bilişüstü Farkındalık ölçeğinden almış oldukları ön test ve son test sonuçlarına Shapiro-Wilks Normallik Testi uygulanmiştır.

Tablo 3. Bilişüstü Farkındalık Ölçeği Ön Test Shapiro-Wilks Normallik Testi Analiz Sonuçları

\begin{tabular}{|c|c|c|c|c|c|c|c|c|}
\hline $\begin{array}{l}\text { Bilişüstü Farkındalık } \\
\text { Ölçeği }\end{array}$ & 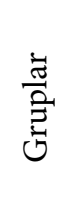 & $\mathrm{N}$ & $\bar{X}$ & S & 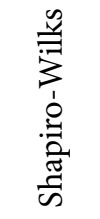 & $\mathrm{P}$ & 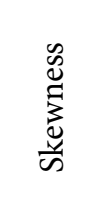 & 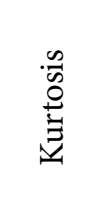 \\
\hline \multirow{2}{*}{ 1.Biliş̧ Bilgisi } & D1 & 30 & 58,46 & 0,99 & 0,837 & $0,000^{*}$ & $-1,993$ & 7,320 \\
\hline & K1 & 30 & 58,76 & 1,16 & 0,912 & $0,017^{\star}$ & $-1,348$ & 3,584 \\
\hline \multirow{2}{*}{ 2.Biliş Düzenlemesi } & D1 & 30 & 125,83 & 2,04 & 0,905 & $0,011^{*}$ & $-1,392$ & 3,803 \\
\hline & K1 & 30 & 124,20 & 3,15 & 0,883 & $0,003^{\star}$ & $-1,336$ & 2,994 \\
\hline \multirow{2}{*}{ Ölçeğin Tümü } & D1 & 30 & 184,30 & 2,91 & 0,865 & $0,001^{*}$ & $-1,796$ & 6,048 \\
\hline & K1 & 30 & 182,96 & 4,14 & 0,894 & $0,006^{*}$ & $-1,432$ & 3,738 \\
\hline
\end{tabular}

$* \mathrm{p}<.05$

Tablo 3' te Bilişüstü Farkındalık Ölçeği ön test Shapiro-Wilks Normallik Testi analiz sonuçları yer almaktadır. Tablo incelendiğinde Deney 1 ve Kontrol 1 grupları ön test verilerinin "p" değerinin her iki alt ölçekte ve ölçeğin tümünde 0,05 'den küçük çıktığ 1 , Skewness ve Kurtosis değelerinin de $(+1,-1)$ aralığını aştığ1 görülmektedir. Bu durumda çalışma gruplarının puanlarının anlamlılık düzeyinde normal dağılımdan sapma gösterdiğgi, verilerin normallik varsayımını karşılamadığı görülerek, grupların verilerinin ön test analizinde parametrik olmayan testler kullanılmıştır.

Tablo 4. Bilişüstü Farkındalık Ölçeği Son Test Shapiro-Wilks Normallik Testi Analiz Sonuçları 


\begin{tabular}{|c|c|c|c|c|c|c|c|c|}
\hline $\begin{array}{l}\text { Bilişüstü } \\
\text { Farkındalık Ölçeği }\end{array}$ & 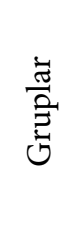 & $\mathrm{N}$ & $\bar{X}$ & S & 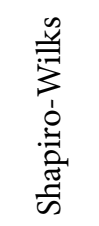 & $\mathrm{P}$ & 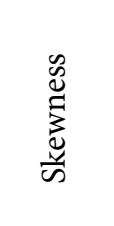 & $\begin{array}{l}\frac{n}{0} \\
\stackrel{0}{0} \\
\stackrel{0}{2}\end{array}$ \\
\hline \multirow{4}{*}{ 1.Biliş Bilgisi } & D1 & 30 & 61,86 & 1,05 & 0,958 & 0,273 & $-0,442$ & $-0,136$ \\
\hline & K1 & 30 & 60,76 & 0,98 & 0,966 & 0,433 & 0,495 & $-0,234$ \\
\hline & $\mathrm{D} 2$ & 30 & 60,96 & 1,30 & 0,978 & 0,766 & $-0,322$ & $-0,343$ \\
\hline & $\mathrm{K} 2$ & 30 & 59,93 & 1,24 & 0,972 & 0,582 & $-0,454$ & 0,734 \\
\hline \multirow{4}{*}{ 2.Biliş Düzenlemesi } & D1 & 30 & 130,56 & 2,05 & 0,945 & 0,127 & 0,209 & $-0,980$ \\
\hline & K1 & 30 & 127,93 & 2,00 & 0,978 & 0,769 & 0,260 & $-0,424$ \\
\hline & D2 & 30 & 129,70 & 2,55 & 0,979 & 0,802 & 0,195 & $-0,420$ \\
\hline & K2 & 30 & 127,50 & 1,91 & 0,965 & 0,411 & 0,280 & $-0,308$ \\
\hline \multirow{4}{*}{ Ölçeğin Tümü } & D1 & 30 & 192,43 & 2,89 & 0,963 & 0,373 & 0,063 & $-0,688$ \\
\hline & K1 & 30 & 188,70 & 2,86 & 0,953 & 0,205 & 0,506 & $-0,428$ \\
\hline & $\mathrm{D} 2$ & 30 & 190,66 & 3,78 & 0,985 & 0,939 & $-0,006$ & $-0,445$ \\
\hline & $\mathrm{K} 2$ & 30 & 187,43 & 2,97 & 0,991 & 0,993 & 0,116 & $-0,111$ \\
\hline
\end{tabular}

$\mathrm{p}>.05$

Tablo 4'te Bilişüstü Farkındalık Ölçeği son test Shapiro-Wilks Normallik Testi analiz sonuçları yer almaktadır. Tablo incelendiğinde Deney 1 ve Kontrol 1 grupları son test verilerinin "p" değerinin her iki alt ölçekte ve ölçeğin tümünde 0,05 'den büyük çıktığ1, Skewness ve Kurtosis değerlerinin de $(+1,-1)$ aralığında olduğu görülmektedir. Bu durumda çalışma gruplarının puanlarının anlamlılık düzeyinde normal dağılımdan sapma göstermediği, verilerin normallik varsayımını karşıladığı görülerek, grupların verilerinin son test analizinde parametrik testler kullanılmıştır.

\section{Bulgu ve Yorumlar}

Araştırmanın denencesi "Yaratıcı drama eğitimiyle yetişen sınıf öğretmeni adayları ile geleneksel öğretim yöntemiyle yetişen sınıf öğretmeni adaylarının bilişüstü farkındalık düzeyleri arasında anlamlı farklılıklar vardır." şeklinde ifade edilmiştir.

Bu denenceye ilişkin istatistiksel çözümlemelerde ilk aşamada Deney 1 ve Kontrol 1 gruplarının deneysel işlem öncesi bilişüstü farkındalık düzeyleri arasında anlamlı farkın olup olmadığına ilişkin ön test yoluyla elde edilen bulguların aritmetik ortalama, standart sapma ve Mann Whitney $U$ testi sonuçlarına bakılmıştır. Daha sonra deneysel işlem sonrası Deney 1, Kontrol 1, Deney 2 ve Kontrol 2 gruplarının son test yolu ile elde edilen bulgularının aritmetik ortalama, standart sapma ve bağımsız t testi sonuçlarına bakılmıştır. Yaratıcı drama eğitiminin gruplar üzerindeki etkisini görmek için Deney 1 ve Kontrol 1 grupları ön test-son test ortalama puanları Wilcoxon İşaretli Sıralar Tesi ile analiz edilmiştir. İkinci aşamada Deney 1 ve Deney 2 gruplarının son testleri bağımsız t-testi ile karşılaştırılarak ön testin etkisi araştırılmıştır. Son olarak da aynı işlem Kontrol 1 ve Kontrol 2 grupları için de ön testin etkisini araştırmak amacıyla gerçekleştirilmiştir. 
Tablo 5. Bilişüstü Farkındalık Ölçeği Deney 1 ve Kontrol 1 Grupları Ön Test Aritmetik Ortalama ve Standart Sapma Değerleri

\begin{tabular}{|l|c|c|c|c|}
\hline \multirow{2}{*}{ Alt Ölçekler } & \multirow{2}{*}{ Grup } & $\mathrm{N}$ & $\bar{X}$ & \multicolumn{2}{|c|}{ Ön Test } \\
\cline { 2 - 5 } & & 30 & 58,46 & 5,47 \\
\hline \multirow{2}{*}{$\begin{array}{l}\text { Biliş } \\
\text { Bilgisi }\end{array}$} & Deney 1 & 30 & 58,76 & 6,36 \\
\cline { 2 - 5 } & Kontrol 1 & 30 & 125,83 & 11,20 \\
\hline $\begin{array}{l}\text { Biliş } \\
\text { Düzenlemesi }\end{array}$ & Deney 1 & 30 & 124,20 & 17,25 \\
\hline \multirow{2}{*}{$\begin{array}{l}\text { Ölçeğin } \\
\text { Tümüi }\end{array}$} & Dentrol 1 & 30 & 184,30 & 15,94 \\
\cline { 2 - 5 } & Kontrol 1 & 30 & 182,96 & 22,69 \\
\hline
\end{tabular}

Tablo 5’te Bilişüstü Farkındalık Ölçeği ön test aritmetik ortalama ve standart sapma değerleri verilmiştir. Buna göre, Biliş Bilgisi Alt Ölçeği Deney 1 grubunun ön test aritmetik ortalaması ( $X=58,46)$, standart sapmas1 $(S=5,47)$ iken, Kontrol 1 grubunun ön test aritmetik ortalaması $(X=58,76)$, standart sapmas1 $(S=6,36)$ 'dır. Biliş Düzenlemesi Alt Ölçeği Deney 1 grubunun ön test aritmetik ortalaması $(X=125,83)$, standart sapması $(\mathrm{S}=11,20)$ iken, Kontrol 1 grubunun ön test aritmetik ortalamas1 $(X=124,20)$, standart sapmas1 $(\mathrm{S}=17,25)^{\prime}$ tir. Ölçeğin bütününe baktığımızda ise Deney 1 grubunun ön test aritmetik ortalaması ( $X=184,30$ ), standart sapmas1 $(\mathrm{S}=15,94)$ iken, Kontrol 1 grubunun ön test aritmetik ortalaması ( $X=182,96)$, standart sapması $(\mathrm{S}=22,69)$ 'dur. Gruplar arasında anlamlı farkın olup olmadığına ilişkin Mann Whitney U Testi çözümlemesi aşağıda verilmiştir. Tablo 6. Bilişüstü Farkındalık Ölçeği Deney 1 ve Kontrol 1 Grupları Ön Test Puanlarına İlişkin Mann Whitney U Testi Sonuçları

\begin{tabular}{|c|c|c|c|c|c|c|}
\hline Alt Ölçekler & Grup & $\mathrm{N}$ & $\begin{array}{c}\text { Sira } \\
\text { Otalaması }\end{array}$ & Sira Toplamı & $\mathrm{U}$ & $\mathrm{p}$ \\
\hline \multirow{2}{*}{$\begin{array}{l}\text { Biliş } \\
\text { Bilgisi }\end{array}$} & Deney 1 & 30 & 29,82 & 894,50 & \multirow{2}{*}{429,50} & \multirow{2}{*}{$\begin{array}{c}0,761 \\
\text { Fark anlamsız. }\end{array}$} \\
\hline & Kontrol 1 & 30 & 31,18 & 935,50 & & \\
\hline \multirow{2}{*}{$\begin{array}{l}\text { Biliş } \\
\text { Düzenlemesi }\end{array}$} & Deney 1 & 30 & 30,90 & 927,00 & \multirow{2}{*}{438,00} & \multirow{2}{*}{$\begin{array}{c}0,859 \\
\text { Fark anlamsız. }\end{array}$} \\
\hline & Kontrol 1 & 30 & 30,10 & 903,00 & & \\
\hline \multirow{2}{*}{$\begin{array}{l}\text { Ölçeğin } \\
\text { Tümü }\end{array}$} & Deney 1 & 30 & 30,60 & 918,00 & \multirow{2}{*}{447,00} & \multirow{2}{*}{$\begin{array}{c}0,965 \\
\text { Fark anlamsız. }\end{array}$} \\
\hline & Kontrol 1 & 30 & 30,40 & 912,00 & & \\
\hline
\end{tabular}

$\mathrm{p}>0,05$ 
Tablo 6'da göre Deney 1 ve Kontrol 1 gruplarının Bilişüstü Farkındalık Ölçeği Biliş Bilgisi alt ölçeği [ $U=429,50, p>0,05]$, Biliş Düzenlemesi Alt Ölçeği [ $U=438,00, p>0,05]$, ve Ölçeğin Tümü [ $U=447,00, p>0,05]$, ön test sonuçları arasında anlamlı bir farklılık yoktur. Bu bulguya göre, Bilişüstü Farkındalık bakımından ön testlerinde anlamlı bir farklılığın olmamasından dolayı, deneysel işlemin başlangıcında grupların bir birine denk olduğu söylenebilir.

Tablo 7. Bilişüstü Farkındalık Ölçeği Deney 1, Kontrol 1, Deney 2 ve Kontrol 2 Grupları Son Test Aritmetik Ortalama ve Standart Sapma Değerleri

\begin{tabular}{|l|c|c|c|c|}
\hline \multirow{3}{*}{ Alt Ölçekler } & \multirow{3}{*}{ Grup } & \multicolumn{3}{|c|}{ Son Test } \\
\cline { 2 - 5 } & & $\mathrm{N}$ & $\bar{X}$ & $\mathrm{~S}$ \\
\hline \multirow{4}{*}{ Biliş Bilgisi } & Deney 1 & 30 & 61,86 & 5,77 \\
\cline { 2 - 5 } & Kontrol 1 & 30 & 60,76 & 5,40 \\
\cline { 2 - 5 } & Deney 2 & 30 & 60,96 & 7,17 \\
\cline { 2 - 5 } & Kontrol 2 & 30 & 59,93 & 6,82 \\
\hline \multirow{4}{*}{ Biliş Düzenlemesi } & Deney 1 & 30 & 130,56 & 11,23 \\
\cline { 2 - 5 } & Kontrol 1 & 30 & 127,93 & 11,00 \\
\cline { 2 - 5 } & Deney 2 & 30 & 129,70 & 13,98 \\
\cline { 2 - 5 } & Kontrol 2 & 30 & 127,50 & 10,48 \\
\hline \multirow{3}{*}{$\begin{array}{l}\text { Ölçeğin } \\
\text { Tümü }\end{array}$} & Deney 1 & 30 & 192,43 & 15,88 \\
\cline { 2 - 5 } & Kontrol 1 & 30 & 198,70 & 15,67 \\
\cline { 2 - 5 } & Deney 2 & 30 & 187,43 & 20,71 \\
\cline { 2 - 5 } & Kontrol 2 & 30 & & 16,28 \\
\hline
\end{tabular}

Tablo 7'de Bilişüstü Farkındalık Ölçeği son test aritmetik ortalama ve standart sapma değerleri verilmiştir. Buna göre, Biliş Bilgisi Alt Ölçeği Deney 1 grubunun son test aritmetik ortalaması ( $X=61,86)$, standart sapması $(\mathrm{S}=5,77)$ iken, Kontrol 1 grubunun son test aritmetik ortalamas1 $(X=60,76)$, standart sapmas1 $(\mathrm{S}=5,40)$ 'dır. Deney 2 grubunun son test aritmetik ortalaması $(X=60,96)$, standart sapması $(\mathrm{S}=7,17)$ iken, Kontrol 2 grubunun son test aritmetik ortalaması $(X=59,93)$, standart sapması $(S=6,82)$ 'tür. Biliş Düzenlemesi Alt Ölçeği Deney 1 grubunun son test aritmetik_ortalaması ( $X=130,56)$, standart sapmas1 $(\mathrm{S}=11,23)$ iken, Kontrol 1 grubunun son test aritmetik ortalamas1 ( $X=127,93)$, standart sapmas1 $(\mathrm{S}=11,00)$ 'dir. Deney 2 grubunun son test aritmetik ortalamas1 $(X=129,70)$, standart sapmas1 $(\mathrm{S}=13,98)$ iken, Kontrol 2 grubunun son test aritmetik ortalaması ( $\bar{X}=127,50)$, standart sapması $(\mathrm{S}=10,48)^{\prime}$ 'dir. Ölçeğin bütününe baktığımızda ise Deney 1 grubunun son test aritmetik ortalamas1 ( $X=192,43)$, standart sapmas1 $(S=15,88)$ iken, Kontrol 1 grubunun son test aritmetik ortalamas1 $(X=188,70)$, standart sapmas1 $(\mathrm{S}=15,67)$ 'dir. Deney 2 grubunun son test aritmetik ortalamas1 $(X$ $=190,66)$, standart sapmas1 $(S=20,71)$ iken, Kontrol 2 grubunun son test aritmetik ortalamas1 $(X=187,43)$, standart sapması ( $S=16,28)$ 'dir. Gruplar arasında anlamlı farkın olup olmadığına ilişkin bağımsız t-testi çözümlemesi aşağıda verilmiştir. 
Tablo 8. Bilişüstü Farkındalık Ölçeği Deney 1, Kontrol 1, Deney 2 ve Kontrol 2 Gruplarl Son Test Puanlarına İlişkin Bă̆ımsız T-Testi Sonuçları

\begin{tabular}{|c|c|c|c|c|c|c|c|}
\hline Alt Ölçekler & Grup & $\mathrm{N}$ & $\bar{X}$ & S & $\mathrm{Sd}$ & $\mathrm{T}$ & $\mathrm{p}$ \\
\hline \multirow{4}{*}{ BilişBilgisi } & Deney 1 & 30 & 61,86 & 5,77 & \multirow{2}{*}{58} & \multirow{2}{*}{0,762} & \multirow{2}{*}{$\begin{array}{c}0,449 \\
\text { Fark anlamsız. }\end{array}$} \\
\hline & Kontrol 1 & 30 & 60,76 & 5,40 & & & \\
\hline & Deney 2 & 30 & 60,96 & 7,17 & \multirow{2}{*}{58} & \multirow{2}{*}{0,572} & \multirow{2}{*}{$\begin{array}{c}0,570 \\
\text { Fark anlamsız. }\end{array}$} \\
\hline & Kontrol 2 & 30 & 59,93 & 6,82 & & & \\
\hline \multirow{4}{*}{$\begin{array}{l}\text { Biliş Düzen- } \\
\text { lemesi }\end{array}$} & Deney 1 & 30 & 130,56 & 11,23 & \multirow[b]{2}{*}{58} & \multirow{2}{*}{0,917} & \multirow{2}{*}{$\begin{array}{c}0,363 \\
\text { Fark anlamsız. }\end{array}$} \\
\hline & Kontrol 1 & 30 & 127,93 & 11,00 & & & \\
\hline & Deney 2 & 30 & 129,70 & 13,98 & \multirow{2}{*}{58} & \multirow[b]{2}{*}{0,689} & \\
\hline & Kontrol 2 & 30 & 127,50 & 10,48 & & & Fark anlamsız. \\
\hline \multirow{4}{*}{ Ölçeğin Tümü } & Deney 1 & 30 & 192,43 & 15,88 & \multirow{2}{*}{58} & \multirow{2}{*}{0,916} & \multirow{2}{*}{$\begin{array}{c}0,363 \\
\text { Fark anlamsız. }\end{array}$} \\
\hline & Kontrol 1 & 30 & 188,70 & 15,67 & & & \\
\hline & Deney 2 & 30 & 190,66 & 20,71 & \multirow{2}{*}{58} & \multirow{2}{*}{0,672} & \multirow{2}{*}{$\begin{array}{c}0,504 \\
\text { Fark anlamsız. }\end{array}$} \\
\hline & Kontrol 2 & 30 & 187,43 & 16,28 & & & \\
\hline
\end{tabular}

$\mathrm{p}>0,05$

Tablo 8'e göre Bilişüstü Farkındalık Ölçeği Biliş Bilgisi Alt Ölçeği Deney 1 ve Kontrol 1 gruplarının son test sonuçları arasında [ $\mathrm{t}(58)=0,762, \mathrm{p}>0,05]$ ve Deney 2 ve Kontrol 2 gruplarının son test sonuçları arasında $[\mathrm{t}(58)=0,572, \mathrm{p}>0,05] \quad$ anlamlı bir farklılık yoktur. Aynı şekilde Biliş Düzenlemesi Alt Ölçeği Deney 1 ve Kontrol 1 gruplarının son test sonuçları arasında [ $\mathrm{t}(58)=0,917, \mathrm{p}>0,05]$ ve Deney 2 ve Kontrol 2 gruplarının son test sonuçları arasında [ $\mathrm{t}(58)=0,689, \mathrm{p}>0,05]$ anlamlı bir farklılık yoktur. Ölçeğin bütününe baktığımızda ise yine Bilişüstü Farkındalık Ölçeği Deney 1 ve Kontrol 1 gruplarının son test sonuçları arasında [ $\mathrm{t}(58)=0,916$, $\mathrm{p}>0,05]$ ve Deney 2 ve Kontrol 2 gruplarının son test sonuçları arasında [ $t(58)=0,672, p>0,05]$ anlamlı bir farklılık yoktur. Bu bulgu, bilişüstü farkındalık bakımından son test sonuçlarına göre Deney ve Kontrol grupları arasında anlamlı bir farklılığın olmadığını göstermektedir. Bu duruma hem deney hem de kontrol gruplarının son testlerindeki artışlarının neden olduğu söylenebilir. Ancak her iki deney gruplarının ortalamalarının kontrol grubu ortalamalarından yüksek olması yaratıcı drama ile işlenen dersin, geleneksel yöntem ile işlenen derse göre öğretmen adaylarının ortalamalarını arttırmada daha etkili olduğunun göstergesi olarak kabul edilebilir.

Aşağıda Bilişüstü Farkındalık Ölçeği Deney 1 ve Kontrol 1 grupları ön test-son test puanları ile yapılan İlişkili Ölçümler Wilcoxon İşaretli Sıralar Testi sonuçları verilmiştir.

Tablo 9. Bilişüstü Farkındalık Ölçeği Deney 1 Grubu Ön Test-Son Test Puanları İlişkili Ölçümler Wilcoxon Işsaretli Stralar Testi Sonuçları 


\begin{tabular}{|c|c|c|c|c|c|c|c|}
\hline \multirow{10}{*}{ 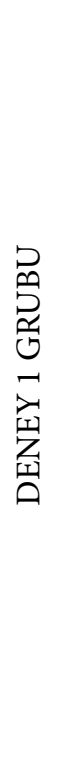 } & \multicolumn{2}{|c|}{ Son test -Ön test } & \multirow{2}{*}{$\begin{array}{l}\mathrm{N} \\
19\end{array}$} & \multirow{2}{*}{$\begin{array}{c}\text { Sira Ortalamas1 } \\
16,13\end{array}$} & \multirow{2}{*}{$\begin{array}{c}\begin{array}{c}\text { Sira } \\
\text { Toplamı }\end{array} \\
306,50\end{array}$} & $\mathrm{Z}$ & $p$ \\
\hline & \multirow{3}{*}{$\begin{array}{l}\text { Biliş } \\
\text { Bilgisi }\end{array}$} & Negatif Sira & & & & \multirow{3}{*}{$2,359^{* *}$} & \multirow{3}{*}{$\begin{array}{c}0,018^{\star} \\
\text { Fark anlamlı. }\end{array}$} \\
\hline & & Pozitif Sira & 9 & 11,06 & 99,50 & & \\
\hline & & Eşit & 2 & - & - & & \\
\hline & \multirow{3}{*}{$\begin{array}{l}\text { Biliş } \\
\text { Düzenlemesi }\end{array}$} & Negatif Sira & 22 & 17,14 & 315,00 & \multirow{3}{*}{$2,110^{\star *}$} & \multirow{3}{*}{$\begin{array}{c}0,035^{\star} \\
\text { Fark anlamlı. }\end{array}$} \\
\hline & & Pozitif Sira & 7 & 14,32 & 120,00 & & \\
\hline & & Eşit & 1 & - & - & & \\
\hline & \multirow{3}{*}{$\begin{array}{l}\text { Ölçeğin } \\
\text { Tümü }\end{array}$} & Negatif Sira & 20 & 17,60 & 352,00 & \multirow{3}{*}{$2,459^{\star *}$} & \multirow{3}{*}{$\begin{array}{c}0,014^{\star} \\
\text { Fark anlamlı. }\end{array}$} \\
\hline & & Pozitif Sura & 10 & 11,30 & 113,00 & & \\
\hline & & Eşit & 0 & - & - & & \\
\hline
\end{tabular}

$* \mathrm{p}<0,000 \quad * *$ ön test $<$ son test $\quad \mathrm{z}=$ Pozitif siralar temeline dayalı

Tablo 9'da Bilişüstü Farkındalık Ölçeği Deney 1 grubu ön test-sontest ortalama puanları ilişkili ölçümler Wilcoxon İşaretli Sıralar sonuçları verilmiştir. Analiz sonuçlarına göre, Deney 1 grubunun hem Biliş Bilgisi alt ölçeği [ $\mathrm{z}=2,359,(\mathrm{p}<0,000)]$, hem Biliş Düzenlemesi alt ölçeği $[\mathrm{z}=2,110,(\mathrm{p}<0,000)]$, hem de ölçeğin bütününde $[\mathrm{z}=2,459,(\mathrm{p}<0,000)]$ deney öncesi ve sonrası puanları arasında anlamlı bir farklılık gözlenmektedir. Ön test - son test aritmetik ortalamaları dikkate alındığında farkın son test lehine olduğu görülmektedir. Bu sonuca göre Deney 1 grubunda yaratıcı drama yöntemiyle işlenen dersin öğretmen adaylarının Bilişüstü Farkındalık düzeylerini arttırmada önemli bir etkisinin olduğu söylenebilir.

Tablo 10. Bilişüstü Farkındalık Ölçeği Kontrol 1 Grubu Ön Test-Son Test Puanları İlişkili Ölçümler Wilcoxon Işsaretli Stralar Testi Sonuçları

\begin{tabular}{|c|c|c|c|c|c|c|c|}
\hline \multirow{10}{*}{ 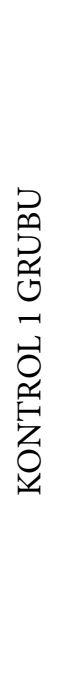 } & \multicolumn{2}{|c|}{ Son test-Ön test } & \multirow{2}{*}{$\begin{array}{c}\mathrm{N} \\
18\end{array}$} & \multirow{2}{*}{$\begin{array}{c}\text { Sira } \\
\text { Ortalaması } \\
16,33\end{array}$} & \multirow{2}{*}{$\begin{array}{c}\begin{array}{c}\text { Sira } \\
\text { Toplamı }\end{array} \\
294,00\end{array}$} & $\mathrm{Z}$ & $\mathrm{p}$ \\
\hline & \multirow{3}{*}{$\begin{array}{l}\text { Biliş } \\
\text { Bilgisi }\end{array}$} & Negatif Sira & & & & \multirow{3}{*}{1,268} & \multirow{3}{*}{$\begin{array}{c}0,205 \\
\text { Fark anlamsiz. }\end{array}$} \\
\hline & & Pozitif Sira & 12 & 14,25 & 171,00 & & \\
\hline & & Eşit & 0 & - & - & & \\
\hline & \multirow{3}{*}{$\begin{array}{l}\text { Biliş } \\
\text { Düzenlemesi }\end{array}$} & Negatif Sira & 18 & 15,39 & 239,50 & \multirow{3}{*}{1,214} & \multirow{3}{*}{$\begin{array}{c}0,225 \\
\text { Fark anlamsiz }\end{array}$} \\
\hline & & Pozitif Sira & 9 & 13,31 & 138,50 & & \\
\hline & & Eşit & 3 & - & - & & \\
\hline & \multirow{3}{*}{$\begin{array}{l}\text { Ölçeğin } \\
\text { Tümü }\end{array}$} & Negatif Sira & 19 & 14,79 & 281,00 & \multirow{3}{*}{1,374} & \multirow{3}{*}{$\begin{array}{c}0,170 \\
\text { Fark anlamsiz }\end{array}$} \\
\hline & & Pozitif Sira & 10 & 15,40 & 154,00 & & \\
\hline & & Eşit & 1 & - & - & & \\
\hline
\end{tabular}

$\mathrm{p}>0,05 \quad \mathrm{z}=$ Pozitif siralar temeline dayal 1 
Tablo 10'da Bilişüstü Farkındalık Ölçeği Kontrol 1 grubu ön test-sontest ortalama puanları ilişkili ölçümler Wilcoxon İşaretli Sıralar sonuçları verilmiştir. Analiz sonuçlarına göre, geleneksel öğrenme ile işlenen dersin olduğu Kontrol 1 grubunun hem Biliş Bilgisi alt ölçeği $[\mathrm{z}=1,268$, (p>0,05)], hem Biliş Düzenlemesi alt ölçeği $[\mathrm{z}=1,214,(\mathrm{p}>0,05)]$, hem de ölçeğin bütününde $[\mathrm{z}=1,374,(\mathrm{p}>0,05)]$ deney öncesi ve sonrası puanları arasında anlamlı bir farklılık elde edilememiştir.

Aşağıda deney grubu lehine farklılaşmada ön testin etkisinin olup olmadığını araştırmak için Deney 1 ve Deney 2 grupları son testlerine ilişkin bağımsız t-testi sonuçları verilmiştir.

Tablo 11. Bilişüstü Farkındalık Ölçeği Deney 1 ve Deney 2 Grupları Son Testlerine İlişskin Bağımsız T-Testi Sonuçları

\begin{tabular}{|c|c|c|c|c|c|c|c|}
\hline Alt Ölçekler & Grup & $\mathrm{N}$ & $\bar{X}$ & S & $\mathrm{Sd}$ & $\mathrm{T}$ & $\mathrm{p}$ \\
\hline \multirow[b]{2}{*}{ Biliş Bilgisi } & Deney 1 & 30 & 61,86 & 5,77 & \multirow[b]{2}{*}{58} & \multirow[b]{2}{*}{0,535} & \multirow[b]{2}{*}{$\begin{array}{c}0,594 \\
\text { Fark anlamsız. }\end{array}$} \\
\hline & Deney 2 & 30 & 60,96 & 7,17 & & & \\
\hline \multirow[b]{2}{*}{ Biliş Düzenlemesi } & Deney 1 & 30 & 130,56 & 11,23 & \multirow[b]{2}{*}{58} & \multirow[b]{2}{*}{0,265} & \multirow{2}{*}{$\begin{array}{c}0,792 \\
\text { Fark anlamsız. }\end{array}$} \\
\hline & Deney 2 & 30 & 129,70 & 13,98 & & & \\
\hline \multirow[b]{2}{*}{ Ölçeğin Tümü } & Deney 1 & 30 & 192,43 & 15,88 & \multirow[b]{2}{*}{58} & \multirow[b]{2}{*}{0,371} & \multirow{2}{*}{$\begin{array}{c}0,712 \\
\text { Fark anlamsız. }\end{array}$} \\
\hline & Deney 2 & 30 & 190,66 & 20,71 & & & \\
\hline
\end{tabular}

$\mathrm{p}>0,05$

Bilişüstü Farkındalık Ölçeği deney gruplarında ön testin etkisinin araştırıldığı Tablo 11' de görüldüğü üzere, Deney 1 ve Deney 2 grupları son testlerine ilişkin bağımsız t-testi sonuçlarına göre Biliş Bilgisi alt ölçeği[ $\mathrm{t}(58)=0,535, \mathrm{p}>0,05]$, Biliş Düzenlemesi alt ölçeği [ $\mathrm{t}(58)=0,265, \mathrm{p}>0,05]$ ve ölçeğin tümünde $[\mathrm{t}(58)=0,371$, $\mathrm{p}>0,05]$. ortalamalar arasında anlamlı farklılık yoktur. Bu da göstermektedir ki; deneysel işlem öncesi ön testin yapılmasının deney gruplarında öğrenme ve duyarlılaşmaya etkisi yoktur.

Tablo 12. Bilişüstü Farkındalık Ölçeği Kontrol 1 ve Kontrol 2 Grupları Son Testlerine İlişkin Bă̆ımsız T-Testi Sonuçları

\begin{tabular}{|c|c|c|c|c|c|c|c|}
\hline Alt Ölçekler & Grup & $\mathrm{N}$ & $\bar{X}$ & S & $\mathrm{Sd}$ & $\mathrm{T}$ & $\mathrm{p}$ \\
\hline \multirow{2}{*}{ Biliş Bilgisi } & Deney 1 & 30 & 60,76 & 5,40 & \multirow{2}{*}{58} & \multirow{2}{*}{0,524} & \multirow{2}{*}{$\begin{array}{c}0,602 \\
\text { Fark anlamsız. }\end{array}$} \\
\hline & Deney 2 & 30 & 59,93 & 6,82 & & & \\
\hline \multirow{2}{*}{ Biliş Düzenlemesi } & Deney 1 & 30 & 127,93 & 11,00 & \multirow{2}{*}{58} & \multirow{2}{*}{0,156} & \multirow{2}{*}{$\begin{array}{c}0,876 \\
\text { Fark anlamsız. }\end{array}$} \\
\hline & Deney 2 & 30 & 127,50 & 10,48 & & & \\
\hline \multirow{2}{*}{ Ölçeğin Tümü } & Deney 1 & 30 & 188,70 & 15,67 & \multirow{2}{*}{58} & \multirow{2}{*}{0,307} & \multirow{2}{*}{$\begin{array}{c}0,760 \\
\text { Fark anlamsız. }\end{array}$} \\
\hline & Deney 2 & 30 & 187,43 & 16,28 & & & \\
\hline
\end{tabular}

$\mathrm{p}>0,05$ 
Bilişüstü Farkındalık Ölçeği kontrol gruplarında ön testin etkisinin araştırıldığı Tablo 12'de görüldüğü üzere, Kontrol 1 ve Kontrol 2 grupları son testlerine ilişkin bağımsız t-testi sonuçlarına göre Biliş Bilgisi alt ölçeği [ $\mathrm{t}(58)=0,524, \mathrm{p}>0,05]$, Biliş Düzenlemesi alt ölçeği [ $\mathrm{t}(58)=0,876, \mathrm{p}>0,05]$ ve ölçeğin tümünde $[\mathrm{t}(58)=0,307$, $\mathrm{p}>0,05]$ ortalamalar arasında anlamlı farklılık yoktur. $\mathrm{Bu}$ da göstermektedir ki; deneysel işlem öncesi kontrol gruplarında tıpkı deney gruplarında olduğu gibi ön testin yapılmasının öğrenme ve duyarlılaşmaya etkisi yoktur.

\section{Sonuç, Tartışma ve Öneriler}

Yurt içi ve yurt dışı yaratıcı drama ile ilgili alan yazın incelendiğinde çok zengin olduğu görülmekle birlikte; yaratıcı drama - bilişüstü farkındalık ilişkisine dair çalışmanın yok denecek kadar az olması bu çalışmanın özgünlüğünü ortaya koymakta ve alandaki boşluğu doldurmaya katkı sağlamayı hedeflemektedir. Bu nedenle öğretmen adaylarının bilişüstü farkındalıkları üzerinde yaratıcı drama eğitimi ve geleneksel öğretim yönteminin etkilerinin araştırıldığı bu araştırmanın bulgularından elde edilen sonuçlar şöyle yorumlanabilir:

Yaratıcı dramanın öğretmen adaylarının bilişüstü farkındalıkları üzerindeki etkisi incelendiğinde; Deney ve Kontrol gruplarının Bilişüstü Farkındalık Ölçeği Biliş Bilgisi alt ölçeği, Biliş Düzenlemesi alt ölçeği ve ölçeğin tümü son test sonuçları arasında anlamlı bir farklılık yoktur. Bu bulgu, bilişüstü farkındalık bakımından son test sonuçlarına göre deney ve kontrol grupları arasında anlamlı bir farklılığın olmadığını göstermektedir. Bu duruma hem deney hem de kontrol gruplarının son testlerindeki artışlarının neden olduğu söylenebilir. Ancak her iki deney gruplarının ortalamalarının kontrol grubu ortalamalarından yüksek olması yaratıcı drama ile işlenen dersin, geleneksel yöntem ile işlenen derse göre daha etkili olduğunun göstergesi olarak kabul edilse de, bu durum anlamlı değildir.

Bilişüstü Farkındalık Ölçeği Deney 1 grubu ön test-son test ortalama puanlarına göre, hem Biliş Bilgisi alt ölçeği, hem Biliş Düzenlemesi alt ölçeği, hem de ölçeğin bütününde deney öncesi ve sonrası puanları arasında anlamlı bir farklı1ık gözlenmektedir. Ön test - son test aritmetik ortalama puanları dikkate alındığında farkın son test lehine olduğu görülmektedir. Bu sonuca göre yaratıcı drama yöntemiyle işlenen dersin geleneksel öğretimle işlenen derse göre öğretmen adaylarının Bilişüstü Farkındalık düzeylerini arttırmada önemli bir etkisinin olduğu söylenebilir. Geleneksel öğrenme ile işlenen dersin olduğu Kontrol 1 grubu ön test-son test ortalama puanlarına göre ise, hem Biliş Bilgisi alt ölçeği, hem Biliş Düzenlemesi alt ölçeği, hem de ölçeğin bütününde deney öncesi ve sonrası puanları arasında anlamlı bir farklılık elde edilememiştir. Bu sonuç yaratıcı drama çalışmalarının öğretmen adaylarının Bilişüstü Farkındalık düzeylerini arttırmada geleneksel öğrenme yöntemine göre daha etkili olduğu sonucunu desteklemektedir.

Bilişüstü Farkındalık Ölçeği deney ve kontrol gruplarında ön testin etkisinin araştırıldığında ise hem Biliş Bilgisi alt ölçeği, hem Biliş Düzenlemesi alt ölçeği ve de ölçeğin tümünde deneysel işlem öncesi ön testin yapılmasının deney ve kontrol gruplarında öğrenme ve duyarlılaşmaya etkisi yoktur. Yurt içi ve yurt dışı alan yazın incelendiğinde bu araştırmanın yöntemi ile benzerlik gösteren bir çalışmaya yurtdışında rastlanmıştır. Johnson (2002) yapmış olduğu çalışmasında drama yöntemi ile çocukların düşünme süreçlerini yansıtmalarını sağlamayı amaçlamıştır. Araştırmanın sonuçları dramanın çocuğun düşünme yetilerini ve bilişüstü farkındalığını güçlendirdiği yönündedir. Johnson'un çalışması ve bu araştırmanın çalışma grubu gelişimsel açıdan farklılıklar gösterse de yaratıcı dramanın öğrencilerin bilişüstü farkındalık düzeylerini arttırmada benzer etkide bulunduğu ve bu araştırmanın sonuçlarının Johonson' un araştırmasını desteklediği söylenebilir. Ancak yurt dışında yapılan Wilburne (1997) bilişüstü eğitimin problem çözme üzerindeki etkilerini incelediği çalışmasında deney ve kontrol grubu arasında anlamlı farklılık elde edememiştir. Yurt içinde ise Özcan (2000) tarafından yapılan çalışmada bilişüstü becerilerin 6.sınıf öğrencilerinin matematik başarısı ve tutumları üzerindeki etkisini incelediği deneysel çalışmasında deney grubu ile kontrol grubu arasında anlamlı farklılık elde edememiştir. Yılmaz (2003) da bilişüstü eğitim ile problem çözme becerileri ilişkisini araştırdığg çalışmasında yine anlamlı farklılık elde edememiştir. Bir başka çalışmada Erdoğan (2008) da bilişüstü eğitimi alan ve almayan grup arasında yine 
anlamlı farklılık elde edememiştir. Gage ve Berlinger (1988) bilişüstü farkındalığın 5-7 yaşlarından itibaren ortaya çıkmaya başladığını ve okul yılları süresince geliştiğini belirtmişlerdir. Mclnerney ve Mclnerney, (2002: 114) de görüşleriyle bunu desteklemektedirler. Onlara göre de bilişüstü farkındalık erken yaşlarda ortaya çıkmakta ve ergenlik boyuna devam etmektedir.

$\mathrm{Bu}$ bilgilere dayanarak yaşları yaklaşı 18 ile 25 yaş arasında değişen öğretmen adaylarının aslında bilişüstü farkındalıklarının tam olarak gelişmiş olması ve bunu öğrenmelerine yansıtmaları beklenmektedir. Ancak ülkemiz koşullarında tam ve nitelikli eğitim alamamış olmanın yanı sıra kültürel ve ekonomik nedenler, hem düşünme becerilerinin tam olarak gelişmesine hem bilişsel hem de bilişüstü yetilerin tam olarak gelişmesine engel teşkil etmektedir. Ayrıca bu çalışmaya ayrılan on haftalık süre de bilişüstü farkındalık gelişimi için tam olarak yeterli olmamış olabilir. Üstelik Çakır İlhan, Okvuran ve Adıgüzel (2004; 4) de drama eğitiminin uzun süreli ve sürece dayalı olarak gerçekleştirildiğinde davranış değişikliği yarattığını belirtmektedirler. Bu durumda çalışmanın başlangıcında kurulan "Yaratıcı drama eğitimiyle yetişen sınıf öğretmeni adayları ile geleneksel öğretim yöntemiyle yetişen sınıf öğretmeni adaylarının bilişüstü farkındalık düzeyleri arasında anlamlı farklılık vardır" denencesinin kısmen doğrulandığ 1 söylenebilir.

Dünyadaki hızlı gelişim, insanın ezbere dayalı bilgi depolamasını değil, yaratıcılık, kendine güven, bağımsız düşünme, öz denetim, problem çözme, kendi öğrenme stratejilerinin farkındalığı, empati, sosyal sorumluluk, sosyal ilişkiler esneklik, strese dayanma dürtü kontrolü, gerçekçi değerlendirme ve uyum gibi potansiyellere sahip olmasını gerektirir. Bu niteliklerin bireylere kazandırılmasında yaratıcı dramanın önemli olduğu bilinmekle birlikte, bu çalışmanın deney grubunu oluşturan öğretmen adaylarının çalışmadan hemen sonra son test olarak elde edilen ve anlamlı farklılık elde edilemeyen sonuçlarının zaman içinde şekillenerek öğretmen adayları tarafından anlamlı boyutlara taşınması umut edilmektedir. Çünkü Adıgüzel (1993: 175), drama çalışmalarının sonuçlarının çalışmalar bittikten bir süre sonra daha iyi belirginleştiğini ifade etmektedir. Buna dayanarak, araştırma ile elde edilen bulguların; öğretmen adayı eğitiminde Bilişüstü Farkındalık ile ilgili olarak yapılacak bilimsel çalışmalara kaynaklık etmesi, Sınıf Öğretmenliği eğitiminde yaratıcı drama ile yapılacak bilimsel çalışmalara katkı ve çeşitlilik sağlaması, Sınıf Öğretmenliği Eğitimi Programı'nın geliştirilmesiyle ilgili yapılacak çalışmalarda işe yarayacak sonuçlar getirmesi ve araştırma sonuçlarının öğretmen eğitimi uygulamalarında yeni düşünce, tartışma ve araştırma konuları yaratması beklenmektedir.

Tüm bunlara dayanarak araştırmaya; öğretmen adaylarının bilişüstü farkındalıkları ile bir yöntem olarak yaratıcı drama arasında daha uzun süreli, farklı deneysel düzenlemelerde ve farklı örneklem üzerinde bu tür çalışmaların tekrarlanması önerisi getirilebilir.

\section{Kaynakça}

Adıgüzel, H. Ö.(1993). Oyun ve yaratıcı drama ilişkisi, Ankara Üniversitesi Eğitim Bilimleri Enstitüsü, Yayımlanmamış Yüksek Lisans Tezi.

Balcı, A. (2001). Sosyal Bilimlerde Araştırma, Yöntem, Teknik ve İlkeler, Ankara: PegemA Yayınları

Blakey, E. ve Spence, S. (1999). “Thinking for the future”. Emergency Librarian, May/June.17, 11-13.

Brown, A. (1987).“Metacognition, executive control, self-regulation, and other more mysterious mechanisms”, In F. Weinert and R. Kluwe (Eds.), Metacognition, Motivation, and Understanding 65-116. NJ.Erlbaum: Hillsdale,

Çakır İlhan, A., Okvuran, A. ve Adıgüzel, Ö.(2004). Drama. İstanbul: Milli Eğitim Bakanlığı Yayınları.

Dawson, T. E. (1997). “A Primer on Experimental and Quasi- Experimental Design”, Paper presented at the annual meeting of the Southwest Educational Research Association, Austin, TX., January.

Erdoğan, S. (2008). Drama ile Matematik Etkinlikleri, Ankara: Nobel Yayın Dağıtım.

Fidan, N. (1986). Okulda Öğrenme ve Öğretme, Ankara: Kadığlu Matbaası. 
Flavell, J. H. (1976). "Metacognitive aspects of problem solving”, In L. R. Resnick (Ed.), The Nature of Intelligence, Hillsdale, NJ: Lawrence Erlbaum.

Flavell, J. H. (1979)."Metacognitive and cognitive monitoring: A New Area of Cognitive Developmental Inquiry”, American Psychologist, 34, 906-911.

Flavell, J. H. (1987). "Speculations about the nature and development of metacognition", In F. Weinert and R. Kluwe (Eds.), Metacognition, Motivation, and Understanding, 21-29. Lawrence Erlbaum: Hillsdale, NJ.

Fraenkel, J. R. ve Wallen, N. E. (2003). How to Design and Evaluate Research in Education, New York: The McGraw Hill Companies Inc. (Fifth ed.).

Gall, M. D., Gall, J. P. ve Borg, W. R. (2003). Educational Research on Introduction, USA, Boston: Allyn and Bacon (Seventh ed.).

Grazino, A. M. ve Raulin, M.L.(2004). Research Methods: A Process of Inquiry. USA: Pearson Education Group, Inc. Fifth ( ed.)

Jacobs, J. E., ve Paris, S. G. (1987). "Children's metacognition about reading: issues in definition, measurement, and instruction”, Educational Psychologist, 22, 255-278.

Johnson, C.(2002). "Drama and metacognition”, Early Child Development and Care, 172, 595-602.

Karasar, N. (2000). Bilimsel Araştırma Yönetimi, Ankara: Nobel Yayın Dağıtım (10.baskı).

Mclneryney, D. M. ve Mclnerney, V.(2002). "Educational Psychology-Constructing Learning”, Pearson Education Australia Pty Limited, Prentice Hall.

Mercer, N. (1998). "Cognition and Context”, Lisbon Partugal: Instituto Superior de Psicologia Aplicada.

Özcan Küçük. Z. Ç. (2000).Bilişüstü becerilerin 6. sınıf öğrencilerine öğretilmesi, Boğaziçi Üniversitesi Ortaöğretim Fen ve Matematik Eğitimi, Yayımlanmamış Yüksek Lisans Tezi

Rosnow, R. L. ve Rosenthal, R.(2002). Beginning Behavioral Research A Conceptual Primer. USA: Pearson-Prentice Hall. (Fourth ed.).

Sawilowsky, S., Kelley, D. L., Blair, R. C. ve Markman, B. S. (1994). "Meta-analysis and the solomon four group design”, Journal of Experimental Education, 62, (4). Summer.

Schraw, G. ve Dennison, R. S.(1994).“Assesing metacognitive awareness”, Contemporary Educational Psychology, 19, 460-475.

Selçioğlu, E. (2010).Yaratıcı dramanın öğretmen adaylarının demokratik tutumları, bilişüstü farkındalıkları ve duygusal zekâ yeterliliklerine etkisi, Dokuz Eylül Üniversitesi Eğitim Bilimleri Enstitüsü, Yayımlanmamış Doktora Tezi

Slawin, R. E. (2003). Educational Psychology, Theory and Practice Boston: Allyn and Bacon, USA.

Wilburne, J. M.(1997). The Effect of teaching metacognition strategies to pre-service elementary school teachers on their mathematical problem-solving achievement and attitude, Temple University Graduate Board, for the degree of doctor of Education, UMI number:9724297

Yıldırım, A. ve Şimşek, H.(2000). Sosyal Bilimlerde Nitel Araştırma Yöntemleri, Ankara: Seçkin Yayınları

Yılmaz, B. H.(2003). Yedinci sınıf öğrencilerinin problem çözme becerilerinde bilişüstü eğitimin etkileri, Boğaziçi Üniversitesi, Ortaöğretim Fen ve Matematik Eğitimi, Yayımlanmamış Yüksek Lisans Tezi 


\section{Summary}

\section{Effects of Creative Drama on Metacognitive Awareness of the Teacher Trainees}

\section{Ebru SELÇIOĞLU DEMIRSÖZ²}

\section{Introduction}

Being aware of cognitive processes and strategies which is realized during his/her learning, and governing his/her learning are explained by metacognition concept. It may also be identified as thinking, understanding and checking his own learning. Metacognition awareness is a planning, sorting and implementing ability that will directly increase individual's performance. Attending creative drama experience and reflections of drama experience have an effect on individual's thinking abilities and metacognition awareness. Because creative drama is an important learning instrument on understanding the information and exploring the concepts. So creative drama is an important method which supports the development of participant's thinking.

\section{Method}

\section{Research Model}

Research design $2 \times 2$ Solomon four groups model is an experimental design. Solomon four groups model is the most powerful experiment model which preserves the internal and external validity together. 1) Becoming different of experimental group related to control group, 2) interaction of pretest (learning, sensitization etc.), 3) differences between pretest and posttest are researched with the Solomon experimental design.

\section{Participants}

Workgroup of the research consists of 4 class, in each one there are 30 preservice teachers having education in Dokuz Eylül University Buca Teachers College Department of Classroom Teaching. Subjects of the workgroup of research were designated by purposeful sampling method. However, considering opportunities of researcher, the workgroup is also a sample for easily accessible situation sampling.

\section{Data Collection}

In this research, "Metacognitive Awareness Inventory", its original was English and was developed by Gregory Schraw and Rayne Sperling Dennison (1994), was used in order to measure the metacognitive awareness of preservice teachers. Language equivalence study of Metacognitive Awareness Scale was made by researcher (Selcioglu Demirsoz, 2010) and Turkish form was developed for available sample.

\section{Results and Conclusion}

When the effect of creative drama on metacognitive awareness of preservice teachers is analyzed; there is not a meaningful difference between the posttest results of Metacognitive Awareness Scale of Experimental and Control groups, Cognitive Data subscale, Cognitive Regulation subscale, and the whole scale. This finding shows that according to posttest results there is not a meaningful difference between experimental and control

2 Assistant Professor Trakya University Education Faculty 
groups in respect of metacognitive awareness. It may be said that this situation was caused because of increase of both experimental and control groups in posttests. Yet, even if an average of each two experimental groups being higher than control group's one is accepted as indicator of that a class with creative drama is more effective than a class with traditional method, this situation is not meaningful. According to the pretest-posttest average points of Metacognitive Awareness Scale Experiment 1 group, a meaningful difference is observed between points of before and after experiment in both Cognitive Data subscale, and Cognitive Regulation subscale, and who whole scale. When arithmetical average points are considered, it is seemed that the difference is on the side of posttest. According to this result, it may be said that a class with creative drama has an important effect on increasing Metacognitive Awareness levels of preservice teachers when compared to class with traditional education. According to pretest-posttest average points of Control 1 group with traditional education, a meaningful difference could not be obtained between points of before and after experiment in both Cognitive Data subscale, and Cognitive Regulation, and the whole scale. This result supports that creative drama studies is more effective than traditional learning method on increasing Metacognitive Awareness levels of preservice teachers. When the effect of pretest in the Metacognitive Awareness Scale experimental and control groups is researched, before experimental process in both Cognitive Data subscale, and Cognitive Regulation subscale, and the whole scale, making pretest has no effect on learning and sensitization of experimental and control groups.

Depending on all these, a new suggestion may be offered that these kinds of works may be repeated about long-term and different experimental planes between metacognitive awareness of preservice teachers and creative drama as method, and different samples. 